\title{
AMERICAN STUDIES ABROAD
}

\author{
By Sune Akerman
}

In one of the articles in this issue professor Ward Miner discusses the advantages and disadvantages for a European scholar to study American conditions. He has for a long time been a visiting professor at different Nordic universities. During that time he has had the opportunity to reflect on his problem. I think that there is a good reason for the members of the NAAS (Nordic Association for American Studies) to withhold judgment as to the disadvantages a little more than Miner does. Within the Association steps have also been taken towards an improved documentation on the US within the Nordic countries but in this field there is still a lot to be done. In this connection, as in others concerning documentation, the amount of facts tends to increase so quickly that it will be very difficult to systematize and make use of the enormous outflow of information.

For the European scholar who wants to study an American subject there soon arises problems very difficult to attack. There is seldom an experienced scholar at the department who can give any advice on the planning of the investigation. Even less often there is somebody to give information about the source material which might be used as the basis for the research. In that case one has to work with descriptions of the material as presented by the Americans. It is obvious that such conditions result in disadvantages. Here we are dealing with threshold difficulties which will gradually disappear when the organizing of education and research on American society will become moae and more common among the Nordic universities. 
As Miner points out, it is quite possible to acquire microfilms of such source material which are easy to transport and use. But only parts of the source material can be provided in that way. Much of it has not been microfilmed and it probably will not be so in spite of the great contributions made at present and those achivoments which will probably be accomplished in the future. Of course it can only cover material of special interest. Xeroxcopies of separate documents can be complementary to the source material but it is very expensive to make copies on a broader scale. Besides it is as a rule necessary to look through a dossier of documents before one decides to copy some of them.

Under such circumstances it will be necessary for the scholar who intends to carry out such an investigation on an American subject to do some research on the spot - at least for a shorter period. This is certainly true for those scholars whose investigations must be based upon field studies. As known it is often possible to make such an arrangement, not the least thanks to the generosity shown by American institutions in giving scholarships to foreign students. On the whole it is also easier than formerly to acquire means in the Nordic countries for such research.

In my opinion achievements must be made to simplify for scholars to get acquainted with a foreign research area. In this connection scientific periodicals play an important part - not the least is that the case with the US. An appropriate selection of such periodicals should be available at the university libraries and at the libraries of the university departments. Furthermore it should be possible to follow up what is published in this field via some documentation service. The risks of double work could not probably ever be eliminated, but it should be noticed that the risks are greater for somebody working on American problems at a European university.

If a research visit to the US has been preceded by acquaintance with the research field in question, and one has been confronted with some essential series of sources, the possibilities increase for research investigations in the US to be efficient, for then some of the difficulties connected with working in foreign archives and libraries will be eliminated. In spite of these difficulties one is apt to agree with Miner's judgment of the great advantages for an 
outsider to analyze another society milieu. The community of values which exists to a very high extent among scholars dealing with the same subject and living in the same country should be questioned by an outsider who has grown up with another tradition. You could also argue that certain types of research problems will suit native scholars better; others will fit more appropriately foreign scholars.

In this issue two lectures from NAAS' last conference, taking place at Otnäs, Finland, are published. In spite of the fact that they deal with history and literary history they take up two problems in Ainerican society very essential today; the racial problem and the tensions between political and military leaders concerning decision-making on top level. It also contains two surveys on American Studies in Finland and in Denmark presented by Jerker A. Eriksson and Eric Jacobsen. There is also a lecture by Olov Fryckstedt, recently appointed professor of Ainerican literature, given at his inauguration. He is the first holder of this schair which means a significant improvement of American Studies in Sweden.

In the Winter issue of 1970 we will start publishing a series of articles on the theme $\gg$ The impact of American research methods on Nordic scholars». In this series we will have scholars representing subjects such as sociology, literature, history etc. to analyze the American influence especially on the adaptation of new research methods. 'The main article of next issue will be »The Quantification Movement in Modern American History» by professor Allan G. Bogue. The article deals with a subject close to the theme and could be considered an introduction to the series. 